\section{Ronald Alfred Brown}

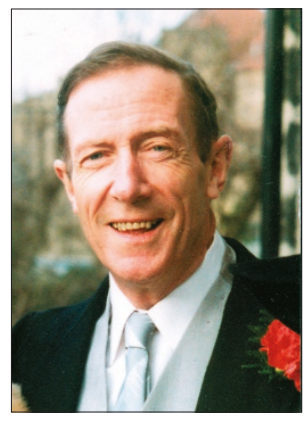

Ronald Brown, 'Ronnie', died in August last year aged 83 in Gosport Hospital after a protracted illness borne with great patience.

He was the oldest of three brothers all of whom were educated by the Jesuits at their day school in Leeds and then went on to qualify at the Leeds Dental Hospital.

Ronald had an unusual professional life. He had already shown a passion for all things seafaring by taking himself off, aged sixteen, to the Arctic Circle in a Hull trawler, an expedition arranged by the owner of the local fish and chip shop. No one was surprised therefore when he applied for a commission in the Royal Navy after qualification and was appointed to serve initially at the Royal Marine base at Lympstone in Devon. Thereafter to the East Indies Fleet, at first in Trincomalee, and then in HMS Jamaica. On leave in 1944 he married Jean Miller, a VAD nurse whose home was also in Leeds.

After the war, the couple set up house in Richmond in Yorkshire, Ronald working in the local practice. The Browns had a happy twelve years in Richmond until the 'pull' of the West coast of Scotland, where they had enjoyed summer holidays, became too strong to resist. They bought a house and nucleus of a dental practice in Loch Carron and Ronald bought a seven ton truck, fitted the interior with chair, dental unit and Mckesson gas machine. The cab, the 'waiting room', was made comfortable with copies of The

\section{Kenneth Peters Liddelow}

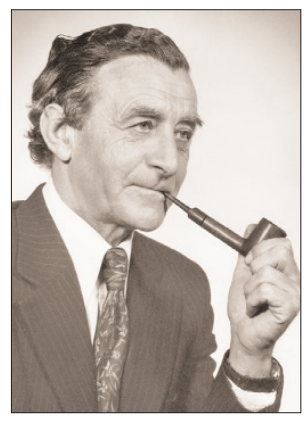

Kenneth Liddelow, an outstanding clinician of his generation with a special interest in dental prosthetics, died on 30 May 2003 aged 87. He earned wide recognition after the war partly due to the publication of his first UK textbook of clinical prosthetic dentistry in collaboration with A.P. Gimson and H.B. Fenn. However, it was his remarkable understanding of oral function and the ability to restore lost tissue that ensured his reputation as an outstanding teacher. When many lecturers were using blackboard and chalk he brought to life the incapacities of persons with missing teeth, facial and jaw tissues, which he recorded on $8 \mathrm{~mm}$ cine colour film. His enlightened approach to the design of prostheses restored the appearance, confidence and function of numerous patients, the secrets of which he shared with dentists who invited him to lecture at BDA branches and specialist societies. A founder member of the British Society for the Study of Prosthetic Dentistry, he was elected president in 1959. The society marked his contribution to the subject with their Gold Medal in 1987.

Liddelow was educated at the City of London School and Guy's Hospital where he graduated in 1938. After service in the RAF Volunteer Reserve he returned to private practice and part time teaching at Guy's before being appointed Head of Prosthetic Dentistry at King's College Hospital Dental School in 1947. He was appointed Professor of Prosthetic Dentistry at the University of London in 1959 and together with Ralph Cocker and other colleagues planned a new building that was opened in 1966. After his appointment as Dean of Dental Studies in 1972 he set about restructuring the school with its enlarged staff. Generations of

\section{Patient appreciation was made manifest}

\section{by the appearance of a fresh salmon on the Browns' doorstep every so often}

Field and Country Life and Jean acted as nurse and receptionist.

The mobile surgery did thousands of miles in Wester Ross along single track roads, over the mountains to Applecross, north east to Sheildaig, on to Kinlochewe, Poolewe, Achnasheen and north to Ullapool, Ronald often away for a week or more. At Kyle of Lochalsh, the Council arranged water supply and drainage for the spittoon at the dock side and and redoubtable elderly ladies came across on the ferry from Skye to have half their teeth removed and then return a week later to finish the job, all with local. There were no vast material riches here but there was immmense satisfaction in providing a much improved dental service for the scattered population. Patient appreciation was made manifest by the appearance of a fresh salmon on the Browns' doorstep every so often.

Ronald moved to Kirkudbright on retirement where he was able to indulge his passion for sailing and ship model making. He was into his seventies when he made the often difficult passage to St Kilda in a schooner owned by the harbour master at Kirkudbright.

Ronald Brown was a man of great charm. Beautiful manners and a gentle sense of humour endeared him to his family, friends and patients. May he rest in peace.

A. G. Brown

\section{Generations of undergraduates remembered him affectionately...}

undergraduates remembered him affectionately as a humane practitioner, sympathetic examiner and understanding dean. He was awarded the Fellowship of King's College London.

From 1965-1977 he served on the dental committee of The Medical Defence Union. He enthusiastically contributed to the making of the film 'Tom Dick and Harriet' which advised students and inexperienced practitioners on ethical behaviour and risks which can lead to claims of negligent practice.

In 1977 Liddelow was appointed Dean of the Faculty of Dental Surgery of the Royal College of Surgeons of England after serving on the board from 1965. He instigated several important changes including the award of the Diploma of Membership in General Dental Surgery and the revision of the examination for the Fellowship in Dental Surgery. He received the prestigious award of the Colyer Gold Medal and was subsequently appointed CBE.

He undertook many important duties including chairmanship of the Dental Sub-committee of the University Grants Committee, visitor of dental schools for the GDC, Consultant Adviser in Prosthetic Dentistry to the Department of Health and Social Security and Consultant Adviser in Dentistry to the RAF.

In 1938 he married Joan Short who sadly died of acute poliomyelitis in 1952. Subsequently, he married Mary Coultard who predeceased him in 1995. Together they raised a combined family of eight children. Before his retirement he moved to the foreshore at Bonchurch, Isle of Wight where he spent many happy years developing their home and garden as well as enjoying watercolour painting.

R. Watson 